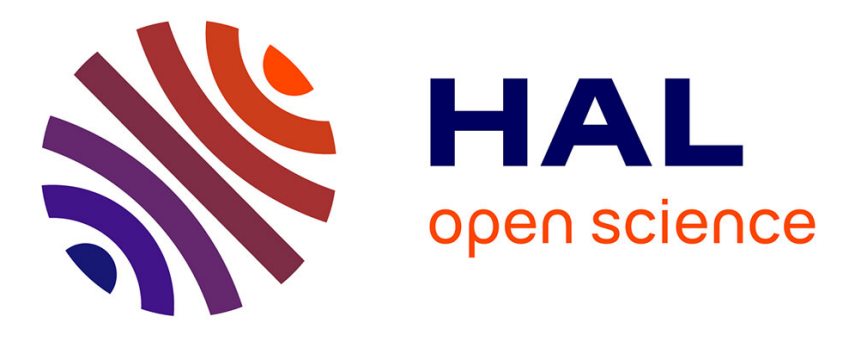

\title{
Glucagon revisited: Coordinated actions on the liver and kidney
}

Lise Bankir, Nadine Bouby, Robert C. Speth, Gilberto Velho, Gilles Crambert

\section{To cite this version:}

Lise Bankir, Nadine Bouby, Robert C. Speth, Gilberto Velho, Gilles Crambert. Glucagon revisited: Coordinated actions on the liver and kidney. Diabetes Research and Clinical Practice, 2018, 10.1016/j.diabres.2018.10.004 . hal-01912646

\section{HAL Id: hal-01912646 https://hal.sorbonne-universite.fr/hal-01912646}

Submitted on 5 Nov 2018

HAL is a multi-disciplinary open access archive for the deposit and dissemination of scientific research documents, whether they are published or not. The documents may come from teaching and research institutions in France or abroad, or from public or private research centers.
L'archive ouverte pluridisciplinaire HAL, est destinée au dépôt et à la diffusion de documents scientifiques de niveau recherche, publiés ou non, émanant des établissements d'enseignement et de recherche français ou étrangers, des laboratoires publics ou privés. 


\title{
Glucagon revisited : \\ Coordinated actions on the liver and kidney
}

\author{
Lise BANKIR ${ }^{1}$, Nadine BOUBY ${ }^{1}$, Robert C. SPETH ${ }^{2,3}$, \\ Gilberto VELHO ${ }^{1}$, and Gilles CRAMBERT ${ }^{1,4}$
}

1. Sorbonne Université, UPMC Univ Paris 06, INSERM, Université Paris Descartes, Sorbonne Paris Cité, UMR_S 1138, Centre de Recherche des Cordeliers, F-75006 Paris, France;

2. Department of Pharmaceutical Sciences, College of Pharmacy, Nova Southeastern University, Fort Lauderdale, FL, USA;

3. Department of Pharmacology and Physiology, College of Medicine, Georgetown University, Washington, DC, USA;

4. CNRS ERL 8228 - Centre de Recherche des Cordeliers - Laboratoire de Métabolisme et Physiologie Rénale, F-75006 Paris, France.

\section{Short title : Glucagon actions on liver and kidney}

Word count: 4212 words (without abstract, figure legends and references)

\section{Corresponding author}

Lise BANKIR, INSERM Unit 1138, Centre de Recherche des Cordeliers 15 rue de l'Ecole de Médecine, 75006 PARIS, France

Tel : 33147353415 or 33682948010

E-mail : lise.bankir@inserm.fr

\section{$\underline{\text { Conflicts of interest }}$}

None of the authors has any conflict of interest to declare. 


\section{Abstract}

Glucagon secretion is stimulated by a low plasma glucose concentration. By activating glycogenolysis and gluconeogenesis in the liver, glucagon contributes to maintain a normal glycemia. Glucagon secretion is also stimulated by the intake of proteins, and glucagon contributes to amino acid metabolism and nitrogen excretion. Amino acids are used for gluconeogenesis and ureagenesis, two metabolic pathways that are closely associated. Intriguingly, cyclic AMP, the second messenger of glucagon action in the liver, is released into the bloodstream becoming an extracellular messenger. These effects depend not only on glucagon itself but on the actual glucagon/insulin ratio because insulin counteracts glucagon action on the liver.

This review revisits the role of glucagon in nitrogen metabolism and in disposal of nitrogen wastes. This role involves coordinated actions of glucagon on the liver and kidney. Glucagon influences the transport of fluid and solutes in the distal tubule and collecting duct, and extracellular cAMP influences proximal tubule reabsorption. These combined effects increase the fractional excretion of urea, sodium, potassium and phosphates. Moreover, the simultaneous actions of glucagon and extracellular cAMP are responsible, at least in part, for the protein-induced rise in glomerular filtration rate that contributes to a more efficient excretion of protein-derived end products.

\section{Keywords}

Insulin, cyclic AMP, glycemia, gluconeogenesis, protein metabolism, urea, glucagon receptors 


\section{Introduction}

Insulin and glucagon are tightly linked, both by the site of their synthesis and by the functions they regulate. Both hormones are secreted by specialized cells of the pancreatic islets (beta and alpha cells, respectively), and both play a role in glucose homeostasis, although with opposite effects. Glucagon stimulates glycogenolysis and gluconeogenesis, inducing a rise in glycemia, whereas insulin favors glucose uptake by cells and storage of glucose in the form of glycogen and lipids, thus reducing glycemia. When these functions were first understood, most studies investigated simultaneously the status of both hormones, using specific immunoassays (developed in the 1960s), and the insulin/glucagon ratio was taken into consideration $[1,2]$. However, in the last few decades, the main focus has been on insulin alone. Glucagon was almost not any more measured, and its possible role not discussed. This lack of interest may be due to technical issues (glucagon is degraded more easily and is more difficult to measure than insulin) and may also be due to the fact glucagon seems less important than insulin in usual conditions. Pancreatectomized patients absolutely need insulin replacement, but do not seem to suffer from the lack of glucagon. This may be because a glucagon-like peptide of higher molecular weight is produced outside of the pancreatic islets [3]. Glucagon secretion is enhanced by starvation which promotes glucose formation. However, glucagon secretion is also potently stimulated by the ingestion of a protein meal or an infusion of amino acids (AAs). This protein-induced rise in glucagon secretion probably occurs much more frequently in our modern life (characterized by the relatively high protein content of Western diets), than stimulation due to starvation.

A few studies suggest that glucagon plays an important role in nitrogen metabolism and in the excretion of nitrogen end-products [4-6]. It also likely contributes to maintenance of potassium homeostasis as explained elsewhere $[7,8]$. In this review, we will focus on the coordinated effects of glucagon on the liver and kidney to regulate glucose and nitrogen handling by these two organs. In addition, we will stress how important for this regulation is the simultaneous concentration of insulin, which reduces the glucagon-induced rise in hepatic cAMP. 


\section{Plasma glucose, insulin and glucagon concentrations throughout the day}

In most human studies, baseline blood samples for various measurement are taken in the morning before breakfast, after a night's fast. For example, glycemia is reported as "fasting glycemia". Intuitively, it may be assumed that glucagon should be elevated in this "fasting" state. However, this is not the case, as will be shown below. In a detailed study, Velho and colleagues measured glycemia, and plasma insulin and glucagon concentrations every half hour for $16 \mathrm{~h}$ in 12 healthy subjects and 7 patients with maturity-onset diabetes of the young (GCK-MODY) [9]. We consider here only the observations reported for the healthy subjects. Figure 1 shows these concentrations over a $16 \mathrm{~h}$ period. The subjects ingested three meals of equal composition ( $60 \%$ carbohydrate, $20 \%$ protein, and $20 \%$ fat) with a well-defined timing during the study. These measurements show several interesting and yet poorly known observations.

1. Although the three meals are similar, the peaks of glycemia and plasma insulin concentration that occur after the $2^{\text {nd }}$ and $3^{\text {rd }}$ meals have a much lower amplitude than those observed after the $1^{\text {st }}$ meal. The larger changes observed in response to the first meal might be related to some degree of insulin resistance occurring in early morning hours, the "dawn phenomenon" well described in diabetic patients [10] as well as in non-diabetic volunteers [11].

2. Between meals, glycemia remains relatively stable around $5 \mathrm{mmol} / \mathrm{L}$, the same level as that observed in the early morning, before the first meal. This good stability occurs in spite of the fact that the body consumes glucose at a high rate, even in the absence of exercise. Only a limited amount of glucose is available at any time in the blood and body fluids (roughly $5 \mathrm{mmol} / \mathrm{L} \times 5 \mathrm{~L}=25 \mathrm{mmol}=5 \mathrm{~g}$ ). The brain alone uses approximately $5 \mathrm{~g}$ glucose per $\mathrm{h}$ and the whole body about $25 \mathrm{~g}$ per $\mathrm{h}$. Thus, outside of meals (that generally provide some glucose), gluconeogenesis and glycogenolysis must operate at a rate that constantly produces glucose in amounts equal to glucose consumption by the body. Noteworthy, even when liver glycogen stores are maximal, gluconeogenesis contributes approximately $50 \%$ to hepatic glucose production [12]. 
3. Plasma glucagon concentration is lower in the early morning than the rest of the day. This shows that the morning fast period is a basal condition, with low glucose needs, that is part of the normal circadian cycle. A more severe fast is required to stimulate glucagon secretion, such as missing one or more meals.

4. Glucagon concentration rises at the time of the first meal, then remaining fairly stable throughout the day, with only modest declines when insulin is at its lowest level, before the next meal. We postulate that this relatively stable level of glucagon throughout the day (about $50 \%$ above that in the early morning) is required to stimulate gluconeogenesis in order to provide the glucose constantly needed for metabolism. This relatively stable glucagon concentration accounts for the relatively stable glycemia. Note that small changes in plasma glucagon concentration parallel those in insulin two $\mathrm{h}$ before and one $\mathrm{h}$ after the lunch and dinner, so that the glucagon/insulin ratio remains fairly stable.

In summary, these measurements in healthy volunteers strongly suggest that glucagon is at its lowest level in the early morning, and that, thereafter, during the whole day, it is secreted at a relatively regular rate to ensure the production of glucose consumed for the body's metabolism.

\section{Glucagon, insulin, and cAMP}

Glucagon action in hepatocytes is mediated by specific membrane receptors that activate adenylate cyclase, thus inducing the formation of CAMP, triggering downstream signaling pathways. In most cells in which cAMP acts as a second messenger of peptidic hormones, cAMP remains intracellular and is degraded by phosphodiesterases into adenosine and phosphate, metabolites that are recycled within the cell. However, in the liver, glucagon-induced cAMP is largely exported out of the hepatocytes into the blood [13-16]. As illustrated in Figure 2A, acute injections of glucagon in healthy subjects induced dose-dependent increases in plasma cAMP concentration $[17,18]$. Some authors assumed that cAMP released by the liver could be involved in an unknown action on a distant organ, because the egress of this metabolite is energetically expensive for the cells and thus, cannot be futile [19, 20]. Insulin is known to counteract glucagon-mediated metabolic actions. This is because, 
insulin accelerates the degradation of glucagon-induced cAMP by stimulating the formation of phosphodiesterases [21]. As a result, intracellular cAMP concentration in hepatocytes and cAMP release into the blood are governed, not just by glucagon but by the insulin/glucagon ratio, as demonstrated in several studies [22, 1, 23, 2] and illustrated in Figure 2B. The most intense effects of glucagon are observed when the insulin/glucagon ratio is low.

After a protein-rich meal, a marked rise in renal blood flow and glomerular filtration rate (GFR) has been well documented and is interpreted as the recruitment of a "functional reserve" [24-26]. Because glucagon secretion is increased after a protein meal (or an AA infusion) [27, 28], the role of glucagon in this hyperfiltration has been strongly suspected, but observations in humans have been inconclusive. Some studies failed to find a significant correlation between the rise in GFR and the plasma glucagon concentration (se review in [29]). Actually, as shown in the study of Claris-Appiani et al [30], the change in GFR observed after an AA infusion (mimicking a protein meal) was not correlated with glucagon itself, but was significantly correlated with the glucagon/insulin ratio (Figure 2C). A few experimental studies suggested that another hormone, released by the liver under the influence of glucagon, was responsible for the protein-induced rise in GFR [31-33]. In an elegant clinical investigation, Giordano et al studied the influence on GFR of 5 different doses of AAs infused in 8 healthy subjects, in random order on separate days, and looked for correlations with a number of hormones [28]. The first 4 doses were designed to span the physiologic level of hyperamino acidemia. As depicted in Figure 2D, the GFR observed in response to these graded AA infusions was dose-dependent and highly correlated with the simultaneous concentration of glucagon in plasma. There was no significant change in any of the other hormones studied (except with growth hormone and insulin for the two highest doses of AAs). Of note, branched-chain AAs that cannot be deaminated in the liver do not induce an increase in renal hemodynamics [34, 35, 33]. In a group of 37 healthy subjects, a significant correlation was observed between GFR (as evaluated by creatinine clearance) and 24-h urinary urea excretion rate [36]. After oral protein loading, there was a significant correlation between GFR (as creatinine clearance) and urinary urea nitrogen excretion rate [36]. 
The elucidation of the role of glucagon in glomerular hyperfiltration came from experimental studies in rats $[6,37,38]$. We showed that an i.v. infusion of glucagon ( $\mathrm{G} 1=1.2 \mathrm{ng} / \mathrm{min} \times 100 \mathrm{~g}$ body weight), raising its concentration in the blood within physiological levels seen after a protein meal, did not increase GFR. Infusing a 10fold higher dose (G10) increased GFR and raised plasma cAMP concentration significantly [38]. A significant rise in GFR was also observed when the low dose of glucagon (G1) was co-infused with cAMP, mimicking its release by the liver (Figure 2E). The 10-fold higher dose of glucagon was needed to produce a "physiologic" concentration in the liver, because endogenous glucagon is secreted into the portal vein and reaches, in the liver, levels that are about one order of magnitude higher than in peripheral blood (the well-known porto-peripheric concentration gradient for pancreatic hormones). Thus, with the 10-fold higher glucagon infusion rate (G10), glucagon was able to stimulate hepatocytes and to induce the release of cAMP into the blood. In experiments with the high dose of glucagon infusion (G10), the rise in GFR was significantly correlated with the simultaneous rise in CAMP. Infusion of CAMP alone did not increase the GFR but reduced proximal tubule reabsorption of sodium, urea, phosphate and other solutes, in a way ressembling that of PTH on this nephron segment [38-40]. How cAMP inhibits proximal tubule reabsorption is not elucidated. Actually, micropuncture studies showed that the effects of glucagon on the proximal tubule and its pars recta mimic those of PTH [41]. Although not considered at that time by the authors, the perfusion rate of glucagon in their experiments ( $5 \mathrm{ng} / \mathrm{min} \times 100 \mathrm{~g}$ body weight) was probably high enough to induce cAMP release by the liver into the bloodstream. Thus, the effects attributed to glucagon in these experiments may possibly be due to cAMP. Some homology has been found between the amino acid sequence of the human PTH receptor and that of cAMP receptors expressed in the amoeba Dictyostelium discoideum [40]. This suggests that the PTH receptor protein could harbor a binding site for extracellular CAMP, as explained in detail elsewhere [40].

The above observations suggest that the metabolic effects of glucagon or insulin on the liver can be well understood only if the concentrations of the two hormones are evaluated simultaneously. They also show that cAMP, released from the liver in amounts depending on the molar ratio between glucagon and insulin, 
plays an important role in the control of kidney function, as explained in greater detail in the next section.

\section{Role of glucagon in urinary nitrogen excretion}

Stimulation of glucagon secretion by starvation and hypoglycemia is wellknown. Glucagon stimulates autophagy to use endogenous AAs as a substrate for gluconeogenesis [42]. However, glucagon secretion is also very sensitive to the blood level of AAs, and plasma glucagon rises markedly in response to a protein meal or an AA infusion (Figure 2D) [27, 43, 44, 28]. In Western countries, where diets are high in protein, this protein-induced stimulation of glucagon release is much more frequent than that due to hypoglycemia. A few authors underlined the fact that glucagon is an important player in protein metabolism and disposal of nitrogen waste products $[4,5,29,45]$. We will focus here on the combined actions of glucagon on urea synthesis by the liver and urea excretion by the kidney.

The main and most well-known action of glucagon in hepatocytes is to stimulate glycogenolysis and/or gluconeogenesis to produce glucose. But actually, when amino acids (general formula : $\mathrm{COOH}-\mathrm{R}-\mathrm{NH}_{2}$ ) are used as a substrate, gluconeogenesis and ureagenesis are always tightly associated [46-48]. The carbon chain of the amino acids $(\mathrm{COOH}-\mathrm{R})$ is used to generate glucose, while the nitrogen of the amino radical $\left(-\mathrm{NH}_{2}\right)$ needs to be excreted because there is no storage of nitrogen in the body. The AAs resulting from the digestion of dietary proteins must be deaminated in order to excrete the nitrogen, mostly in the form of urea. After a protein-rich meal, AAs are used in the liver for gluconeogenesis rather than for protein synthesis [45]. The carbon chain of the AAs is used for gluconeogenesis, in parallel with ureagenesis, even if an increased supply of glucose is not needed at that time. Thus, glucose is produced after a protein-rich meal, independently of the glucose needs of the body, as a consequence of the need to excrete nitrogen. Actually, glucagon is a potent activator of the five enzymatic steps of the ornithineurea cycle that leads to urea synthesis in the liver [49-52]. Moreover, glucagon also influences kidney function in several ways that help the body excrete nitrogen end products, as detailed below. 
Glucagon receptors are strongly expressed in the kidney $[53,54]$. Because the nephron comprises many different subsegments, it is important to determine which segments/cell types respond to glucagon. A microassay of cAMP in microdissected single, well defined nephron segments revealed that glucagon stimulates adenylyl cyclase activity in the medullary and cortical thick ascending limb (TAL), the distal convoluted tubule (DCT) and the collecting duct (CD), as shown in Figure 3A [53, 55]. The medullary TAL is the segment in which this stimulation is the most intense. Binding of radiolabeled glucagon in rat kidney and transcriptomic data from the human kidney confirmed a strong expression of the glucagon receptor [56] and its mRNA in the same segments [57]. Assessing the binding of radiolabelled glucagon on rat kidney slices using the technique of autoradiography [58] reveals an intense binding in the inner stripe of the outer medulla, as shown in Figures 3B and 3D. This heavy labeling is likey localized in the medullary TALs. A weaker but significant labelling is also present in the renal cortex, in the medullary rays where cortical TALs and CDs are running, as shown in Figure $3 \mathrm{C}$. These autoradiograms do not allow resolution of the different cell types that express glucagon receptors, but they fit well with the activation of adenylate cyclase in individual nephron segments exposed to glucagon, and with the functional effects on electrolyte transport observed after infusion of glucagon in vivo [59, 41, 37].

Glucagon exerts both direct and indirect effects on the kidney. The direct effects occur in the distal nephron segments and collecting ducts that express the glucagon receptor. The indirect effects are mediated by extracellular cAMP (largely derived from the liver) and take place in the proximal tubule [37]. GFR increases after a protein-rich meal, but not after a carbohydrate- or lipid-rich meal. The catabolism of carbohydrates and lipids produces only $\mathrm{CO}_{2}$ and $\mathrm{H}_{2} \mathrm{O}$ that are easily excreted by the lungs and kidneys, respectively. But the end-products of protein catabolism include nitrogen wastes (urea, ammonia, uric acid, creatinine) as well a phosphates, sulfates, protons, etc... that are not only excreted by the kidney but are concentrated in the urine far above their level in plasma and body fluids [60, 61]. Glucagon plays a crucial role in favoring the excretion of these waste products by the kidney in two ways. First, it participates in the rise in GFR (along with vasopressin, see review in [29]), and second, it inhibits the reabsorption of urea along the nephron, thus 
improving the fractional excretion of urea [6, 37]. These effects require both glucagon itself plus extracellular CAMP released from the liver into the bloodstream in response to glucagon, as explained above.

More than a century ago, it was shown, in rats, that a high protein diet induced a marked kidney hypertrophy, while a high carbohydrate or lipid diet did not, neither did an amount of urea added to the food, bringing the same load of nitrogen as did the protein diet. Thus dietary proteins imposed an increased "work" to the kidney that urea alone did not (see review in [62]). In his landmark treatis "Glomerulonephritis" in 1949, Thomas Addis explained that the low protein diet recommended to patients with chronic kidney disease (before dialysis was available) was intended to reduce the "concentrating burden" on the kidney [63]. In experiments designed to better understand the influence of glucagon on the kidney, we observed that an infusion of glucagon significantly increased the GFR by about $20 \%$ and the urinary urea excretion rate by $65 \%[6,37$ ] (Figure 4A). Surprisingly, this marked increase did not reduce plasma urea concentration (Figure 4B). This meant that, under the influence of glucagon, ureagenesis by the liver had increased to the same extent as did urea excretion by the kidney. The greater urea excretion was accounted for by the rise in GFR (for about $1 / 3^{\text {rd }}$ ) and the reduction of urea reabsorption along the nephron (for about $2 / 3^{\text {rd }}$ ). The fractional excretion of urea (that is the fraction of the filtered urea remaining in the urine) rose from $42 \%$ to $60 \%$ (Figure 4C). Interestingly, the glucagon-induced change in GFR was significantly and positively correlated with the simultaneous changes in plasma cAMP concentration and in the urine-to-plasma urea concentration ratio (Figure 4D).

If urea was infused instead of glucagon, in order to raise urinary urea excretion rate to the same extent, a marked rise in plasma urea concentration was observed (Figure 4B) and neither the GFR nor the fractional excretion of urea were affected [38]. This shows that glucagon influences kidney function by means other than just increasing the plasma load of urea. Actually, as explained above, glucagon, in concentrations observed in peripheral blood after a protein meal, does not increase GFR (Figure 2E). A simultaneous rise in plasma glucagon and cAMP concentrations is required $[38,40]$. 
These observations highlight the coordinated actions of glucagon on the liver and kidney which promote an optimal handling of protein waste products by simultaneously increasing urea synthesis in the liver and efficient urea excretion by the kidney. The effects on the kidney result from the combined actions of glucagon plus glucagon-induced liver-derived extracellular cAMP. The possible mechanism by which these two actors regulate renal function are described elsewhere $[40,29,7]$. Briefly, it likely involves a simultaneous reduction in proximal tubule solute and water reabsorption (induced by cAMP) and the stimulation of $\mathrm{NaCl}$ reabsorption in the water-tight TAL (induced by glucagon). These combined actions reduce the concentration of sodium in the tubular fluid at the macula densa and enhance that of urea (the osmolality of the tubular fluid remaining the same). This in turn reduces the tubulo-glomerular feedback control of GFR [64-67]. Downstream, within the kidney, several additional mediators or factors (shown to play a role in hyperfiltration) come into play to mediate this feedback control of GFR (renin-angiotensin system, nitric oxide, prostaglandins, etc....). As previously mentioned, the glucagon-induced increase in GFR is significantly correlated to the rise in the urine-to-plasma concentration ratio of urea (Figure 4D). This ratio likely reflects the proportion of urea versus that of other solutes in the tubular fluid at the macula densa [37]. Note that the intensity of this effect depends on the amount of cAMP released by the liver under the influence of the glucagon/insulin molar ratio.

No hyperfiltration occurs after a protein meal in pancreatectomized patients (who thus cannot secrete glucagon in response to protein intake) [68-70]. The lack of glucagon-induced rise in plasma cAMP and resulting action on the proximal tubule may explain why glucagon receptor antagonism in humans induces an increase in ambulatory blood pressure [71]. This is likely due to a too intense Na reabsorption in the proximal tubule. In the same line, subjects who suffer a partial loss-of-function mutation of the glucagon receptor have higher blood pressure and a more avid $\mathrm{Na}$ reabsorption in the proximal tubule [72].

Of note, glucagon also favors a relative water economy in the excretion of urea by improving the ability to concentrate an increased load of solutes in the urine [6]. This tubular effect is additive to that of vasopressin [73] and probably results from the direct action of glucagon on the TAL, the nephron segment that plays a crucial role in 
the counter-current multiplication process [74]. In experiments presented in Figure 4 and Figure 2E, the effects of glucagon or other compounds were studied in the presence of a constant infusion of the selective vasopressin V2 receptor agonist dDAVP to exclude a possible confounding influence of changes in vasopressin secretion $[6,37,38]$.

\section{Synthesis and conclusion}

It may seem strange that glucagon secretion is enhanced both when there is a lack of food and when there is an intake of protein-rich food. This enhanced secretion in two apparently opposed situations is best explained by the fact that glucagon should not be considered solely as a gluco-regulatory hormone but also as an important player in the disposal of nitrogen wastes, whether they come from endogenous or exogenous sources. The independent regulation of both glycemia and excretion of nitrogen end products is achieved by the combined effects of glucagon and insulin, resulting in a coordinated regulation of metabolic functions by the liver and excretory functions by the kidney. Figure $\mathbf{5}$ schematically depicts these two associated roles of glucagon. In the case of hypoglycemia induced by starvation, or after the ingestion of a protein meal (even if glycemia is normal), glucagon is secreted and promotes the use of AAs for simultaneous gluconeogenesis and ureagenesis, two associated metabolic pathways that take place in the liver. In the case of starvation, AAs come from endogenous sources, mostly muscle and liver, whereas in the case of a protein meal, AAs come from the ingested proteins. During starvation, insulin secretion is low and thus, glucagon effects are not attenuated by the counter-regulatory action of insulin. In contrast, in the case of a protein meal, insulin secretion goes up in response to some of the dietary amino acids [27] and to the glucagon-induced rise in glycemia. Insulin favors the use of this extra glucose for post-prandial thermogenesis and/or storage in glycogen and fatty acids.

Simultaneously, glucagon and liver-generated extracellular CAMP favor a more efficient disposal of nitrogen end-products by increasing GFR and reducing tubular reabsorption of urea (and some other solutes) [41, 37]. 
During the day, a relatively stable level of glucagon in the blood stimulates gluconeogenesis (and ureagenesis) to sustain the metabolic demand of the body, and insulin concentration is relatively low (Figure 1). At any time, the intensity of the response to glucagon will depend on the resulting glycemia and the ensuing secretion of insulin that contributes to reduce glucagon-induced cAMP accumulation in hepatocytes and cAMP release into the bloodstream.

The observations reported above show that extracellular cAMP is a hepatorenal link that regulates solute reabsorption in the pars recta of the proximal tubule. cAMP egress from hepatocytes is well characterized and probably occurs via an organic acid transporter [75]. cAMP has been shown to bind renal brush border membrane vesicles [76], and luminal cAMP inhibits proximal tubule reabsorption, as does PTH [77]. Liver-generated extracellular CAMP also participates, in conjunction with glucagon, to the regulation GFR. Insulin, by its inhibitory influence on glucagoninduced cAMP release by the liver, weakens the indirect (cAMP-mediated) influence of glucagon on renal function.

Of note, hyperglucagonemia, either induced by exogenous glucagon infusion or due to a glucagon-secreting tumor, leads to a significant decline in plasma AAs [78]. Conversely, interruption of glucagon receptor signalling results in a hyper-amino acidemia [79]. In diabetes mellitus, it is well understood that the exaggerated catabolism and elevated glycemia are not due to (or not only to) the lack of insulin or to insulin receptor unresponsiveness, but also to an enhanced glucagon secretion [80-84]. Glucagon receptor antagonists have been proposed to reduce the unwanted effects of glucagon on hyperglycemia in type 2 diabetes [85, 84, 86]. But adverse side effects will probably preclude the use of this therapeutic strategy [87, 71].

The facts reported in this review highlight the importance of the balance between insulin and glucagon in the control of carbohydrate and nitrogen metabolism. An imbalance between the two hormones and the resulting level of livergenerated cAMP release into the blood may explain several poorly understood clinical conditions such as some dysregulations of natriuresis and blood pressure control, glomerular hyperfiltration of diabetes mellitus, hepato-renal syndrome, edema observed in kwashiorkor, etc.... as detailed elsewhere [40]. Thus, for a better 
understanding of metabolic disorders and kidney function associated with pancreatic islets dysfunction, it is important to take into account, not only insulin, but also glucagon and plasma cAMP concentrations.

\section{Acknowledgments}

L.B. wants to thank Pascal Ferré (Centre de Recherche des Cordeliers, Paris, France) for stimulating discussions about glucoregulation and for advices regarding some sections of this review.

${ }^{125} \mathrm{I}-\mathrm{Nle}^{27}$ glucagon was prepared by the Peptide Radioiodination Shared Resource, Georgetown University. Technical assistance for the receptor autoradiography was provided by Leena Couling, Andrea Linares, and Hong Pang. 


\section{Legends}

Figure 1. Concentrations of glucose, insulin and glucagon in plasma of 12 healthy, lean, Caucasian men, over a period of $16 \mathrm{~h}$ (means $\pm \mathrm{SE}$ ). The subjects ingested three meals of equal composition at the times shown by vertical arrows. Adapted from Velho et al [9].

Figure 2. Importance of insulin and cAMP in the study of glucagon effects.

2A. Dose-dependent effect of acute i.v. injection of glucagon on plasma cAMP concentration during the subsequent $15 \mathrm{~min}$ in healthy humans. Adapted from Hendy et al [18].

2B. The concentration of CAMP in liver tissue - and likely the release of liverborne cAMP into the circulation - depends upon the Insulin/Glucagon molar ratio. Reproduced from Seitz et al [1].

2C. The change in GFR observed in response to the infusion of a mixture of amino acids was significantly correlated with the plasma glucagon/insulin concentration ratio $(r=0.40, P<0.05)$, but not with plasma glucagon concentration alone (not shown). Redrawn after Claris-Appiani et al [30]. 2D. Relationship between GFR and plasma glucagon concentration in a group of healthy humans during basal state and after infusion of graded doses of amino acid designed to span the physiological range of post-prandial hyperamino-acidemia. Increases in GFR were closely correlated with plasma glucagon concentration $(r=0.99, P<0.001)$, but not with that of insulin, $G H$, or IGF-I (not shown). Reproduced from Giordano et al [28].

2E. The changes in GFR observed in response to the infusion of glucagon at a small dose (G1, $1.2 \mathrm{ng} / \mathrm{min} \times 100 \mathrm{~g}$ body weight), ) or at a ten-fold higher dose (G10), or urea, cAMP, or glucagon (low dose) with cAMP. Adapted from Ahloulay et al [38].

Figure 3. Localization of glucagon receptors in the kidney.

3A. Diagram of a rat nephron and collecting duct. The dot density in the different segments is proportional to the intensity of glucagon-induced 
adenylate cyclase activity. CTAL and MTAL = cortical and medullary TAL, respectively; $C D=$ collecting duct. Adapted from Morel [55].

$\underline{3 B}$ to $\mathbf{D}$. Autoradiograms showing glucagon binding to rat kidney sections. Kidneys from adult male Sprague-Dawley rats were removed and frozen at minus $80^{\circ} \mathrm{C}$. Twenty $\mu \mathrm{m}$ thick sections were cut with a cryostat microtome and mounted on glass slides. $\mathrm{Nle}^{27}$ glucagon (Abclonal Technology, Woburn, MA) was radioiodinated with ${ }^{125}$ at $\sim 10: 1$ ratio of peptide to iodine and was purified by reverse phase HPLC. After preincubation for $30 \mathrm{~min}$, the kidney sections were incubated for $1 \mathrm{~h}$ with $200 \mathrm{pM}{ }^{125} \mathrm{l}-\mathrm{Nle}^{27}$ glucagon with or without $3 \mu \mathrm{M}$ unlabeled glucagon, to distinguish glucagon receptor binding from non-specific binding (NS, not shown). Sections were rinsed, dried under a stream of air, and apposed to X-Ray film (Biomax MR-1) for 1 to 8 days to produce a latent image of the bound ${ }^{125} \mathrm{I}-\mathrm{Nle}^{27}$ glucagon. The film images were captured by scanning into an image analysis system (MCID) at $2400 \mathrm{dpi}$.

3B. Whole kidney longitudinal section.

3C. Detail of the cortex and outer stripe of outer medulla.

3D. Detail of the inner stripe of outer medulla.

CO, cortex; OS and IS, outer stripe and inner stripe of the outer medulla, respectively; IM, inner medulla; P, papilla. Lab = labyrinthic zone of the cortex, containing all the convoluted proximal and distal tubules; MR = medullary rays of the cortex in which all straight nephron segments are running in parallel (pars recta, thick ascending limb, collecting duct). VB and IB, vascular bundle and interbundle region, respectively. Note the punctuate labeling in the cortex probably corresponding to distal tubules and collecting ducts. Note also the heavy labelling of the interbundle regions in the IS, contrasting with the poor labeling in the OS and IM.

Figure 4. Influence of intravenous infusion of glucagon or urea in rats.

$\underline{4 A}$ to $C$. Urea was infused so as to increase urea excretion rate as much as did the infusion of glucagon. Glucagon increased urea excretion rate without inducing a fall in plasma urea concentration. Glucagon, but not urea, induced a prompt and significant increase in the fractional excretion of urea. Adapted from Ahloulay et al [6]. 
4D. Relationship between the glucagon-induced increase in GFR ( $\Delta$ GFR) and the simultaneous change in the urine/plasma urea concentration ratio $(\Delta U / P$ urea), a ratio that is most likely proportional to the tubular fluid/plasma urea concentration ratio at the macula densa. Regression lines are shown. Closed symbols = glucagon infusion $(p<0.01)$; open symbols = saline infusion (control) (NS). Adapted from Ahloulay et al [37].

Figure 5. Schematic representation comparing hepato-renal relationships in two conditions in which glucagon secretion is stimulated : starvation or protein intake. In both cases, amino acids need to be deaminated and the resulting nitrogen excreted. In the first case, glucose production is required to maintain glycemia, and amino acids come from endogenous tissues, whereas in the second case, amino acids come from the ingested proteins. 


\section{Reference list}

1. Seitz HJ, Muller MJ, Nordmeyer P, Krone W, Tarnowski W. Concentration of cyclic AMP in rat liver as a function of the insulin/glucagon ratio in blood under standardized physiological conditions. Endocrinology. 1976;99(5):1313-8.

2. Kalra S, Gupta Y. The Insulin:Glucagon Ratio and the Choice of GlucoseLowering Drugs. Diabetes therapy : research, treatment and education of diabetes and related disorders. 2016;7(1):1-9.

3. Mashiter K, Harding PE, Chou M, Mashiter GD, Stout J, Diamond D, Field JB. Persistent pancreatic glucagon but not insulin response to arginine in pancreatectomized dogs. Endocrinology. 1975;96(3):678-93.

4. Miller LL. Glucagon: a protein catabolic hormone in the isolated perfused rat liver. Nature. 1960;185:248.

5. Holst JJ. Glucagon-how to prove its role in amino acid metabolism. Europ J Clin Invest. 1983;13:107-108.

6. Ahloulay M, Bouby N, Machet F, Kubrusly M, Coutaud C, Bankir L. Effects of glucagon on glomerular filtration rate and urea and water excretion. The American journal of physiology. 1992;263(1 Pt 2):F24-F36.

7. Bankir L, Bouby N, Blondeau B, Crambert G. Glucagon actions on the kidney revisited: possible role in potassium homeostasis. American journal of physiology Renal physiology. 2016;311(2):F469-86.

8. Bankir L, Barbato A, Russo O, Crambert G, lacone R, Bouby N, Perna L, Strazzullo P. Renal potassium handling in carriers of the Gly40Ser mutation of the glucagon receptor suggests a role for glucagon in potassium homeostasis. Physiological reports. 2018;6(8):e13661.

9. Velho G, Petersen KF, Perseghin G, Hwang JH, Rothman DL, Pueyo ME, Cline GW, Froguel P, Shulman GI. Impaired hepatic glycogen synthesis in glucokinase-deficient (MODY-2) subjects. The Journal of clinical investigation. 1996;98(8):1755-61.

10. Carroll MF, Schade DS. The dawn phenomenon revisited: implications for diabetes therapy. Endocrine practice : official journal of the American College of Endocrinology and the American Association of Clinical Endocrinologists. 2005;11(1):55-64.

11. Bolli GB, De Feo P, De Cosmo S, Perriello G, Ventura MM, Calcinaro F, Lolli C, Campbell P, Brunetti P, Gerich JE. Demonstration of a dawn phenomenon in normal human volunteers. Diabetes. 1984;33(12):1150-3. 
12. Petersen KF, Price T, Cline GW, Rothman DL, Shulman GI. Contribution of net hepatic glycogenolysis to glucose production during the early postprandial period. The American journal of physiology. 1996;270(1 Pt 1):E186-91.

13. Broadus AE, Kaminsky NI, Northcutt RC, Hardman JG, Sutherland EW, Liddle GW. Effects of glucagon on adenosine 3',5'-monophosphate and guanosine 3',5'-monophosphate in human plasma and urine. The Journal of clinical investigation. 1970;49(12):2237-45.

14. Exton JH, Lewis SB, Ho RJ, Park CR. The role of cyclic AMP in the control of hepatic glucose production by glucagon and insulin. Advances in Cyclic Nucleotide Research. 1972;1:91-101.

15. Kuster J, Zapf J, Jakob A. Effects of hormones on cyclic AMP release in perfused rat livers. FEBS letters. 1973;32(1):73-7.

16. Sovik O, Heiervang E, Aksnes L, Selvig S. Responses of plasma adenosine 3',5'-monophosphate, blood glucose and plasma insulin to glucagon in humans. Scandinavian journal of clinical and laboratory investigation. 1981;41(7):669-74.

17. Kaminsky NI, Broadus AE, Hardman JG, Jones DJ, Jr., Ball JH, Sutherland EW, Liddle GW. Effects of parathyroid hormone on plasma and urinary adenosine 3',5'-monophosphate in man. The Journal of clinical investigation. 1970;49(12):2387-95.

18. Hendy GN, Tomlinson S, O'Riordan JL. Impaired responsiveness to the effect of glucagon on plasma adenosine $3^{\prime}: 5^{\prime}$-cyclic monophosphate in normal man. European journal of clinical investigation. 1977;7(3):155-60.

19. Kelly LA, Wu C, Butcher RW. The escape of cyclic AMP from human diploid fibroblasts: general properties. J Cyclic Nucleotide Res. 1978;4(6):423-435.

20. Barber R, Butcher RW. The egress of cyclic AMP from metazoan cells. Adv Cyclic Nucleotide Res. 1983;15:119-138.

21. Ishibashi K, Fujioka T, Ui M. Insulin increased cAMP phosphodiesterase activity antagonizing metabolic actions of glucagon in rat hepatocytes cultured with herbimycin A. European journal of pharmacology. 2000;409(2):109-21.

22. Felig P, Gusberg R, Hendler R, Gump FE, Kinney JM, Mulrow PJ. Concentrations of glucagon and the insulin:glucagon ratio in the portal and peripheral circulation. Proceedings of the Society for Experimental Biology and Medicine Society for Experimental Biology and Medicine (New York, NY). 1974;147(1):88-90.

23. Seitz HJ, Muller MJ, Krone W, Tarnowski W. Coordinate control of intermediary metabolism in rat liver by the insulin/glucagon ratio during starvation and after glucose refeeding. Regulatory significance of long-chain acyl-CoA and cyclic AMP. Archives of biochemistry and biophysics. 1977;183(2):647-63. 
24. Amiel C, Blanchet F, Friedlander G, Nitenberg A. Renal functional reserve. Nephrology, dialysis, transplantation : official publication of the European Dialysis and Transplant Association - European Renal Association. 1990;5(9):763-70.

25. Bosch JP. Renal reserve: a functional view of glomerular filtration rate. Seminars in nephrology. 1995;15(5):381-5.

26. Palsson R, Waikar SS. Renal Functional Reserve Revisited. Advances in chronic kidney disease. 2018;25(3):e1-e8.

27. Rocha DM, Faloona GR, Unger RH. Glucagon-stimulating activity of 20 amino acids in dogs. The Journal of clinical investigation. 1972;51(9):2346-51.

28. Giordano M, Castellino P, McConnell EL, DeFronzo RA. Effect of amino acid infusion on renal hemodynamics in humans: a dose-response study. The American journal of physiology. 1994;267(5 Pt 2):F703-F708.

29. Bankir L, Roussel R, Bouby N. Protein- and diabetes-induced glomerular hyperfiltration : role of glucagon, vasopressin, and urea. American journal of physiology Renal physiology. 2015:ajprenal.00614.2014.

30. Claris-Appiani A, Ardissino G, Tirelli AS, Dacco V, Corbetta C, Guidi L, Moretto $\mathrm{E}$, Assael BM, Sereni F. Metabolic factors in the renal response to amino acid infusion. American journal of nephrology. 1998;18(5):359-66.

31. Premen AJ. Importance of the liver during glucagon-mediated increases in canine renal hemodynamics. The American journal of physiology. 1985;249(2 Pt 2):F319-F322.

32. Alvestrand A, Zimmerman L, Bergstrom J. Potential role of a liver-derived factor in mediating renal response to protein. Blood purification. 1988;6(5):276-84.

33. Wada L, Don BR, Schambelan M. Hormonal mediators of amino acid-induced glomerular hyperfiltration in humans. The American journal of physiology. 1991;260(6 Pt 2):F787-92.

34. Claris-Appiani A, Assael BM, Tirelli AS, Cavanna G, Corbetta C, Marra G. Proximal tubular function and hyperfiltration during amino acid infusion in man. American journal of nephrology. 1988;8(2):96-101.

35. Premen AJ. Nature of the renal hemodynamic action of amino acids in dogs. The American journal of physiology. 1989;256(4 Pt 2):F516-F523.

36. Lew SW, Bosch JP. Effect of diet on creatinine clearance and excretion in young and elderly healthy subjects and in patients with renal disease. Journal of the American Society of Nephrology : JASN. 1991;2(4):856-65. 
37. Ahloulay M, Dechaux M, Laborde K, Bankir L. Influence of glucagon on GFR and on urea and electrolyte excretion: direct and indirect effects. The American journal of physiology. 1995;269(2 Pt 2):F225-F35.

38. Ahloulay M, Dechaux M, Hassler C, Bouby N, Bankir L. Cyclic AMP is a hepatorenal link influencing natriuresis and contributing to glucagon-induced hyperfiltration in rats. The Journal of clinical investigation. 1996;98(10):2251-8.

39. Bankir L, Martin H, Dechaux M, Ahloulay M. Plasma cAMP: a hepatorenal link influencing proximal reabsorption and renal hemodynamics? Kidney international Supplement. 1997;59:S50-S56.

40. Bankir L, Ahloulay M, Devreotes PN, Parent CA. Extracellular cAMP inhibits proximal reabsorption: are plasma membrane cAMP receptors involved? American journal of physiology Renal physiology. 2002;282(3):F376-F392.

41. de Rouffignac C, Elalouf JM, Roinel N. Glucagon inhibits water and $\mathrm{NaCl}$ transports in the proximal convoluted tubule of the rat kidney. Pflugers Archiv : European journal of physiology. 1991;419(5):472-7.

42. Ezaki J, Matsumoto N, Takeda-Ezaki M, Komatsu M, Takahashi K, Hiraoka Y, Taka H, Fujimura T, Takehana K, Yoshida M, Iwata J, Tanida I, Furuya N, Zheng DM, Tada N, Tanaka K, Kominami E, Ueno T. Liver autophagy contributes to the maintenance of blood glucose and amino acid levels. Autophagy. 2011;7(7):727-36.

43. Bosch JP, Saccaggi A, Lauer A, Ronco C, Belledonne M, Glabman S. Renal functional reserve in humans. Effect of protein intake on glomerular filtration rate. The American journal of medicine. 1983;75(6):943-50.

44. Castellino P, Hunt W, DeFronzo RA. Regulation of renal hemodynamics by plasma amino acid and hormone concentrations. Kidney international Supplement. 1987;22:S15-20.

45. Kraft G, Coate KC, Winnick JJ, Dardevet D, Donahue EP, Cherrington AD, Williams PE, Moore MC. Glucagon's effect on liver protein metabolism in vivo. American journal of physiology Endocrinology and metabolism. 2017;313(3):E263-e272.

46. Kashiwagura T, Erecinska M, Wilson DF. pH dependence of hormonal regulation of gluconeogenesis and urea synthesis from glutamine in suspensions of hepatocytes. The Journal of biological chemistry. 1985;260(1):407-14.

47. Schutz Y. Protein turnover, ureagenesis and gluconeogenesis. International journal for vitamin and nutrition research Internationale Zeitschrift fur Vitaminund Ernahrungsforschung Journal international de vitaminologie et de nutrition. 2011;81(2-3):101-7. 
48. Ipata PL, Pesi R. Understanding the interrelationship between the synthesis of urea and gluconeogenesis by formulating an overall balanced equation. Advances in physiology education. 2017;41(2):286-290.

49. Snodgrass PJ, Lin RC, Muller WA, Aoki TT. Induction of urea cycle enzymes of rat liver by glucagon. The Journal of biological chemistry. 1978;253(8):2748-53.

50. Brebnor L, Phillips E, Balinsky JB. Control of urea cycle enzymes in rat liver by glucagon. Enzyme. 1981;26(5):265-70.

51. Husson A, Buquet C, Vaillant R. Induction of the five urea-cycle enzymes by glucagon in cultured foetal rat hepatocytes. Differentiation; research in biological diversity. 1987;35(3):212-8.

52. Vilstrup H, Hansen BA, Almdal TP. Glucagon increases hepatic efficacy for urea synthesis. J Hepatol. 1990;10(1):46-50.

53. Bailly C, Imbert-Teboul M, Chabardes D, Hus-Citharel A, Montegut M, Clique A, Morel F. The distal nephron of rat kidney: a target site for glucagon.

Proceedings of the National Academy of Sciences of the United States of America. 1980;77(6):3422-4.

54. Svoboda $M$, Tastenoy $M$, Vertongen $P$, Robberecht $P$. Relative quantitative analysis of glucagon receptor mRNA in rat tissues. Molecular and cellular endocrinology. 1994;105(2):131-7.

55. Morel F. Sites of hormone action in the mammalian nephron. The American journal of physiology. 1981;240(3):F159-F164.

56. Butlen D, Morel F. Glucagon receptors along the nephron: [125I]glucagon binding in rat tubules. Pflugers Archiv : European journal of physiology. 1985;404(4):348-53.

57. Chabardes-Garonne D, Mejean A, Aude JC, Cheval L, Di Stefano A, Gaillard MC, Imbert-Teboul M, Wittner M, Balian C, Anthouard V, Robert C, Segurens B, Wincker P, Weissenbach J, Doucet A, Elalouf JM. A panoramic view of gene expression in the human kidney. Proceedings of the National Academy of Sciences of the United States of America. 2003;100(23):13710-5.

58. Linares A, Couling LE, Carrera EJ, Speth RC. Receptor Autoradiography Protocol for the Localized Visualization of Angiotensin II Receptors. Journal of visualized experiments : JoVE. 2016(112).

59. Friedlander G, Blanchet-Benqué F, Bailly C, Assan R, Amiel C. Tubular effects of glucagon in humans [Effets tubulaires rénaux du glucagon chez l'homme] (in French]. Médecine/Sciences. 1985;1:100-103.

60. Bankir L, Bouby N, Trinh-Trang-Tan MM, Ahloulay M, Promeneur D. Direct and indirect cost of urea excretion. Kidney international. 1996;49(6):1598-607. 
61. Bankir L, Bouby N, Ritz E. Vasopressin: a novel target for the prevention and retardation of kidney disease? Nature reviews Nephrology. 2013;9(4):223-39.

62. Bouby N, Trinh-Trang-Tan MM, Kriz W, Bankir L. Possible role of the thick ascending limb and of the urine concentrating mechanism in the proteininduced increase in GFR and kidney mass. Kidney international Supplement. 1987;22:S57-61.

63. Addis T. Glomerular nephritis. Diagnosis and treatement. New York: The Macmillan Company; 1949. pp 338 p.

64. Seney FD, Wright FS. Dietary protein suppresses feedback control of glomerular filtration in rats. J Clin Invest. 1985;75:558-568.

65. Seney FD. Tubuloglomerular feedback regulation of GFR during infusion of glucagon. Xth Int Cong Nephrol,. 1987; London:561 (abstract).

66. Seney FD, Persson AEG, Wright FS. Modification of tubuloglomerular feedback signal by dietary protein. Am J Physiol. 1987;252 (Renal Fluid Electrolyte Physiol. 21):F83-F90.

67. Seney FD, Marver JD. Protein intake and cation transport in the loop of Henle. Journal of Laboratory and Clinical Medicine. 1989;114:587-594.

68. DeSanto NG, Coppola S, Anastasio P, Coscarella G, Capasso G, Castellino P, DeMercato R, Bellini L, Strazzullo P, Guadagno P, Pignatelli C.

Pancreatectomy abolishes the renal hemodynamic response to a meat meal in man. Nephron. 1990;55:85-86.

69. Friedlander G, Blanchet-Benque F, Nitenberg A, Laborie C, Assan R, Amiel C. Glucagon secretion is essential for aminoacid-induced hyperfiltration in man. Nephrology, dialysis, transplantation : official publication of the European Dialysis and Transplant Association - European Renal Association. 1990;5(2):110-7.

70. Premen AJ, Powell DA, Carroll RG, Dobbins DE. Renal vascular response to amino acids: effect of pancreatectomy. The American journal of physiology. 1990;258(5 Pt 2):F1154-63.

71. Kazda CM, Frias J, Foga I, Cui X, Guzman CB, Garhyan P, Heilmann C, Yang JA, Hardy TA. Treatment with the glucagon receptor antagonist LY2409021 increases ambulatory blood pressure in patients with type 2 diabetes. Diabetes, obesity \& metabolism. 2017;19(8):1071-1077.

72. Strazzullo P, lacone R, Siani A, Barba G, Russo O, Russo P, Barbato A, D'Elia $\mathrm{L}$, Farinaro E, Cappuccio FP. Altered renal sodium handling and hypertension in men carrying the glucagon receptor gene (Gly40Ser) variant. Journal of molecular medicine (Berlin, Germany). 2001;79(10):574-80. 
73. Elalouf JM, Sari DC, de Rouffignac C. Additive effects of glucagon and vasopressin on renal $\mathrm{Mg}$ reabsorption and urine concentrating ability in the rat. Pflugers Archiv : European journal of physiology. 1986;407 Suppl 2:S66-S71.

74. Sands JM, Layton HE. The physiology of urinary concentration: an update. Seminars in nephrology. 2009;29(3):178-95.

75. Rindler MJ, Bashor MM, Spitzer N, Saier MH, Jr. Regulation of adenosine 3':5'monophosphate efflux from animal cells. The Journal of biological chemistry. 1978;253(15):5431-6.

76. Insel $\mathrm{P}$, Balakir R, Sacktor $\mathrm{B}$. The binding of cyclic AMP to renal brush border membranes. Journal of cyclic nucleotide research. 1975;1(2):107-22.

77. Butlen D, Jard S. Renal handling of $3^{\prime}-5^{\prime}$-cyclic AMP in the rat. The possible role of luminal $3^{\prime}-5$ '-cyclic AMP in the tubular reabsorption of phosphate. Pflugers Archiv : European journal of physiology. 1972;331(2):172-90.

78. Almdal TP, Heindorff $\mathrm{H}$, Bardram L, Vilstrup $\mathrm{H}$. Increased amino acid clearance and urea synthesis in a patient with glucagonoma. Gut. 1990;31(8):946-8.

79. Galsgaard KD, Winther-Sorensen M, Orskov C, Kissow H, Poulsen SS, Vilstrup H, Prehn C, Adamski J, Jepsen SL, Hartmann B, Hunt J, Charron MJ, Pedersen $\mathrm{J}$, Wewer Albrechtsen NJ, Holst JJ. Disruption of glucagon receptor signaling causes hyperaminoacidemia exposing a possible liver-alpha-cell axis. American journal of physiology Endocrinology and metabolism. 2018;314(1):E93-e103.

80. Lefebvre PJ, Luyckx AS. Glucagon and diabetes: a reappraisal. Diabetologia. 1979;16(6):347-54.

81. Almdal TP. Importance of glucagon for nitrogen loss in diabetes--via an accelerated hepatic conversion of amino nitrogen to urea nitrogen. Danish medical bulletin. 1991;38(2):113-20.

82. Li XC, Liao TD, Zhuo JL. Long-term hyperglucagonaemia induces early metabolic and renal phenotypes of Type 2 diabetes in mice. Clinical science (London, England : 1979). 2008;114(9):591-601.

83. Gosmain Y, Masson MH, Philippe J. Glucagon: the renewal of an old hormone in the pathophysiology of diabetes. Journal of diabetes. 2013;5(2):102-9.

84. Lefebvre PJ, Paquot N, Scheen AJ. Inhibiting or antagonizing glucagon: making progress in diabetes care. Diabetes, obesity \& metabolism. 2015;17(8):720-5.

85. Shen DM, Lin S, Parmee ER. A survey of small molecule glucagon receptor antagonists from recent patents $(2006$ - 2010). Expert opinion on therapeutic patents. 2011;21(8):1211-40. 
86. Scheen AJ, Paquot N, Lefebvre PJ. Investigational glucagon receptor antagonists in Phase I and II clinical trials for diabetes. Expert opinion on investigational drugs. 2017;26(12):1373-1389.

87. Guzman CB, Zhang XM, Liu R, Regev A, Shankar S, Garhyan P, Pillai SG, Kazda C, Chalasani N, Hardy TA. Treatment with LY2409021, a glucagon receptor antagonist, increases liver fat in patients with type 2 diabetes. Diabetes, obesity \& metabolism. 2017;19(11):1521-1528. 

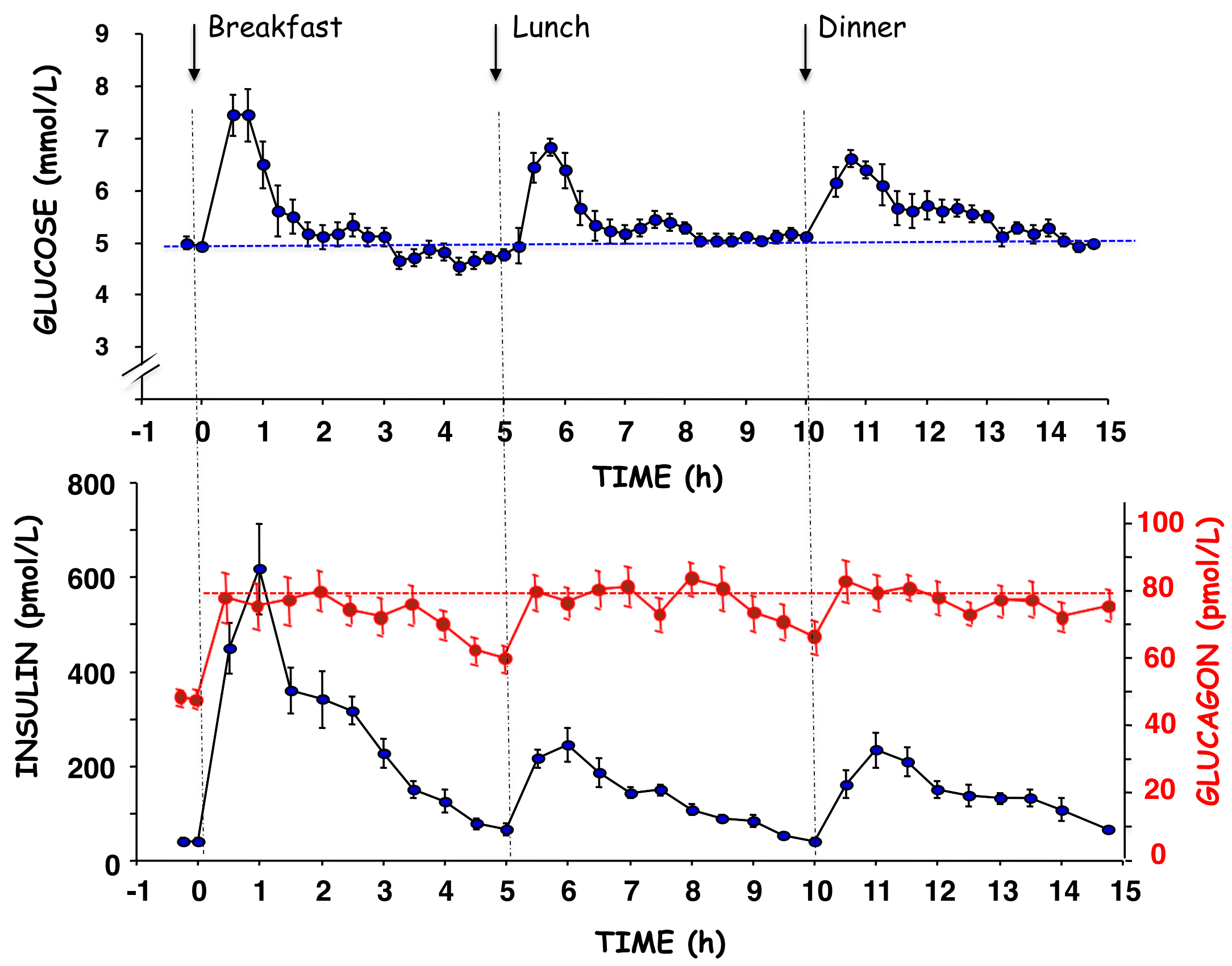
A

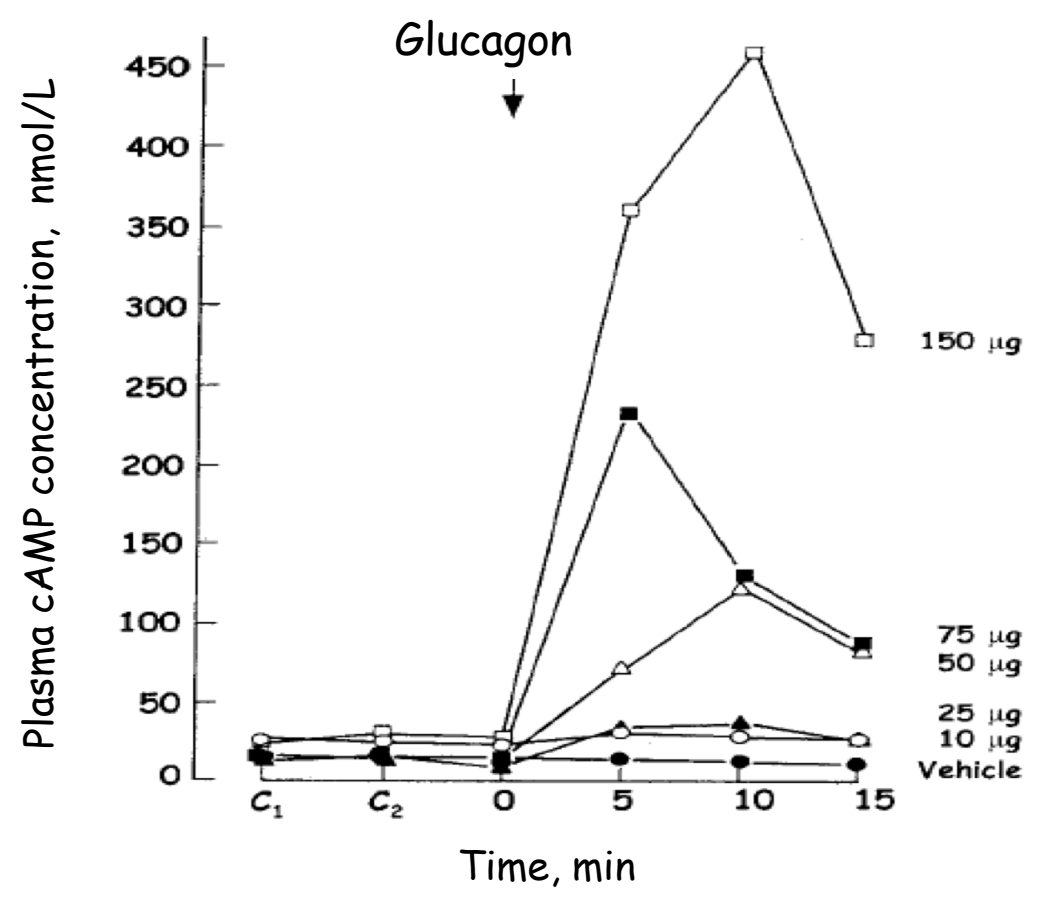

B

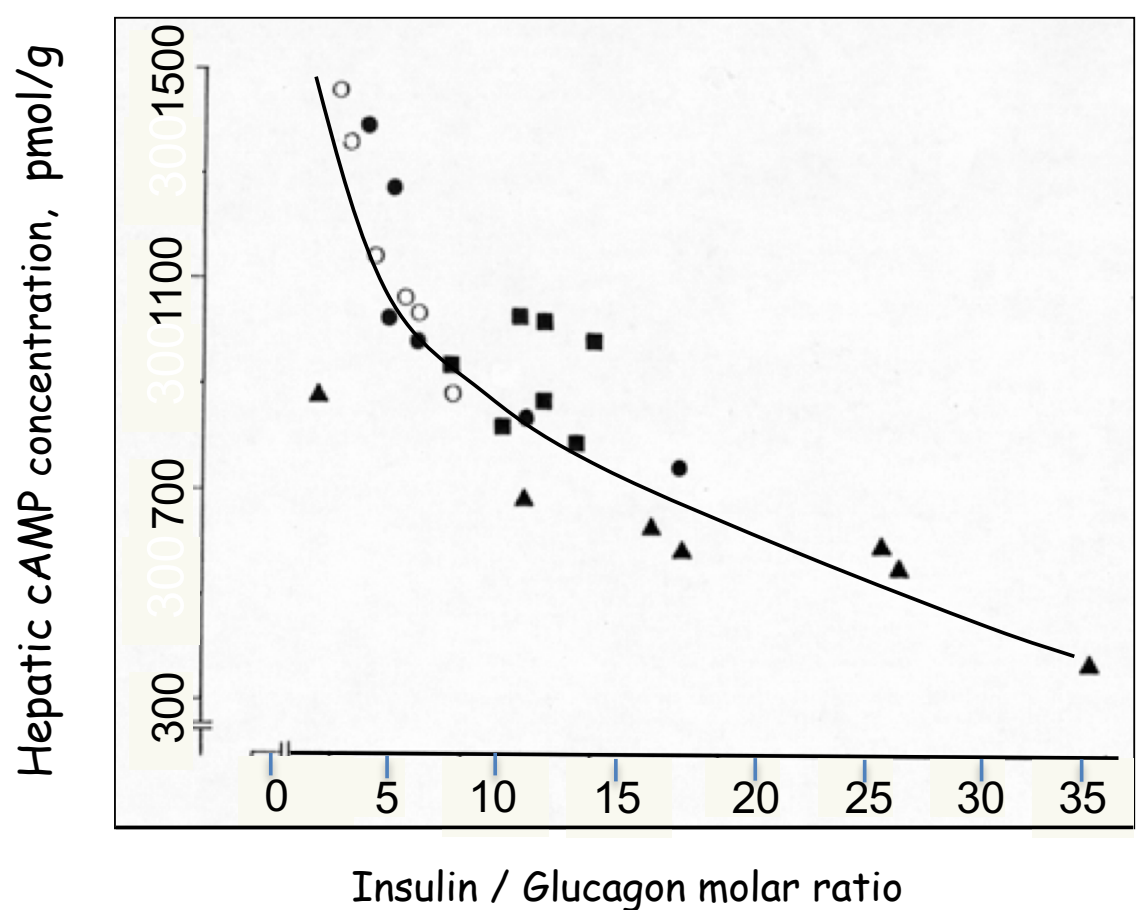

C

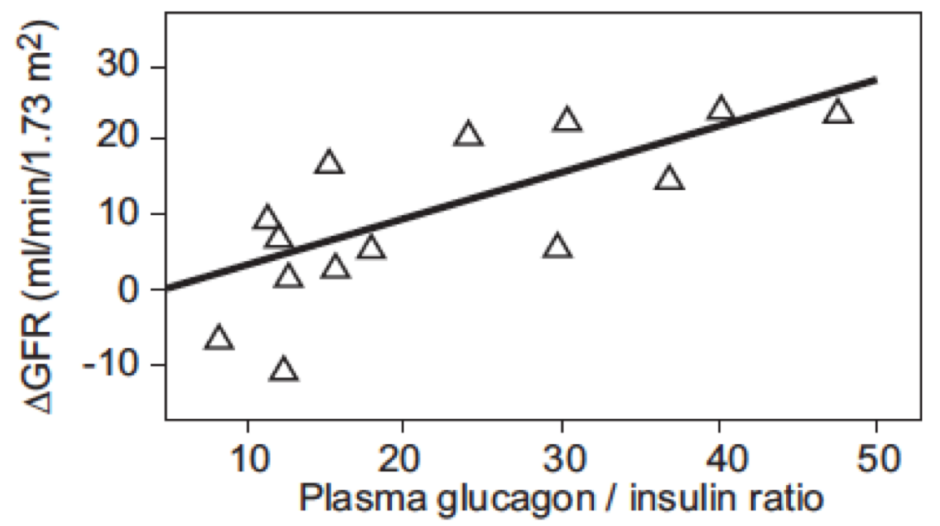

D

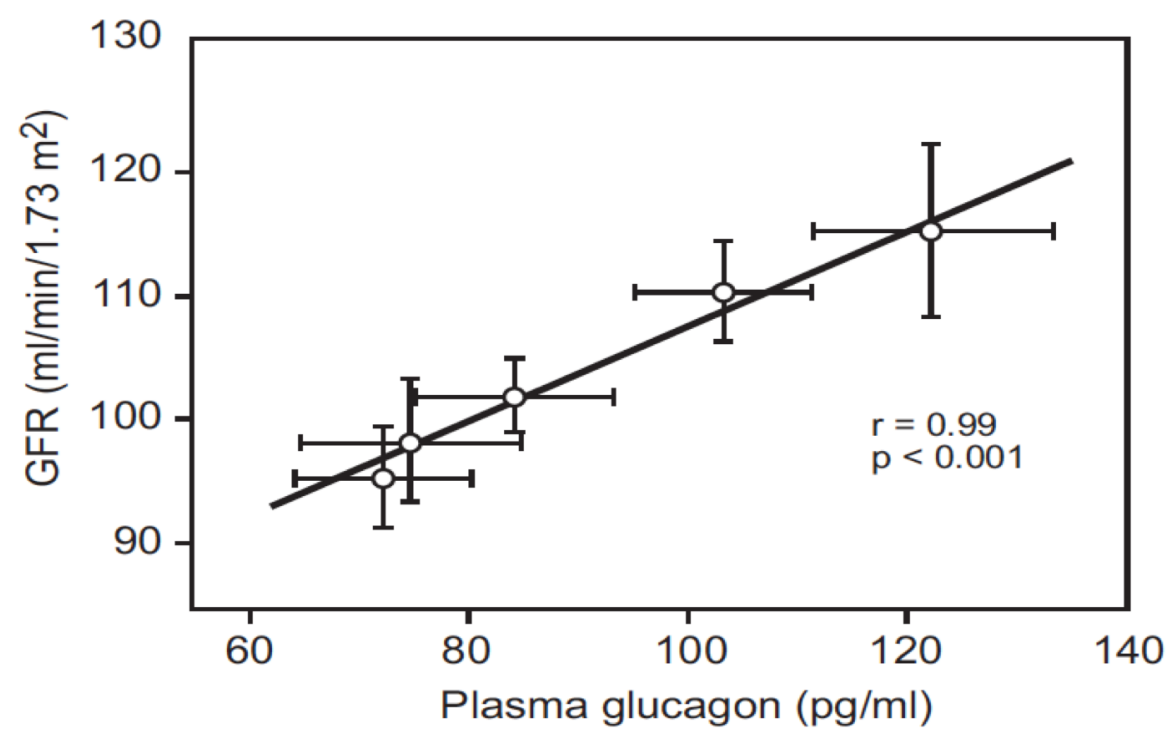

E

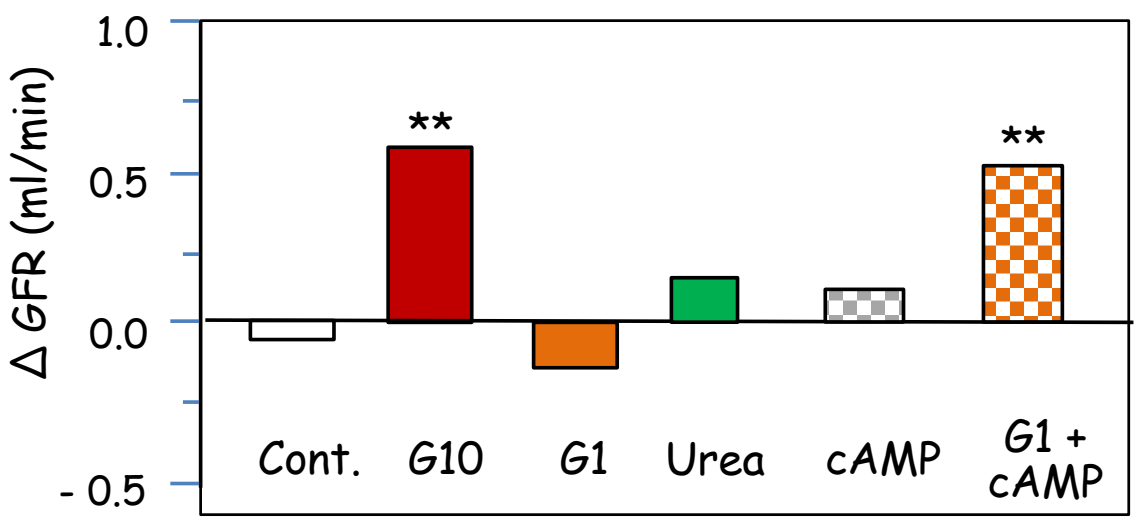



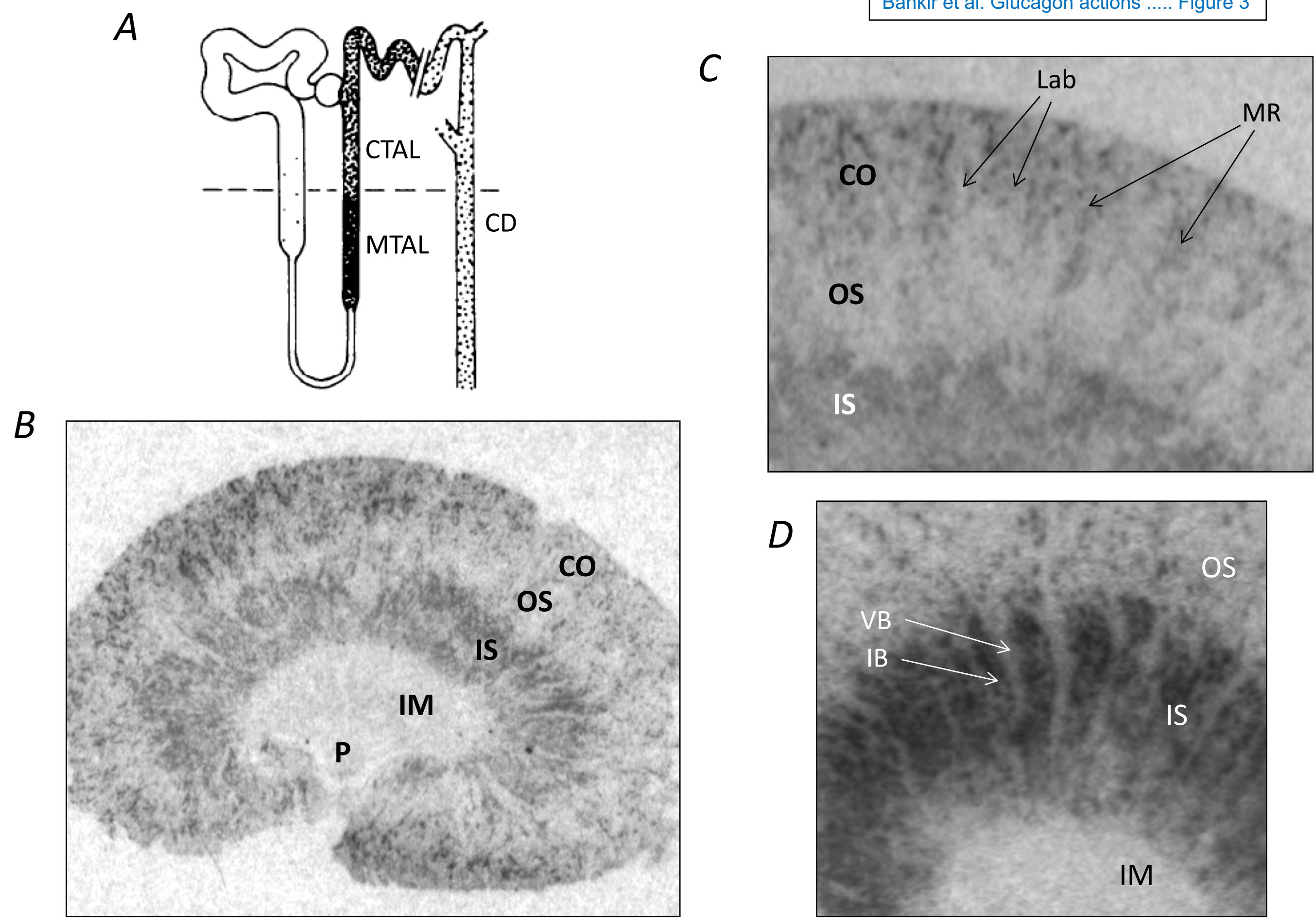

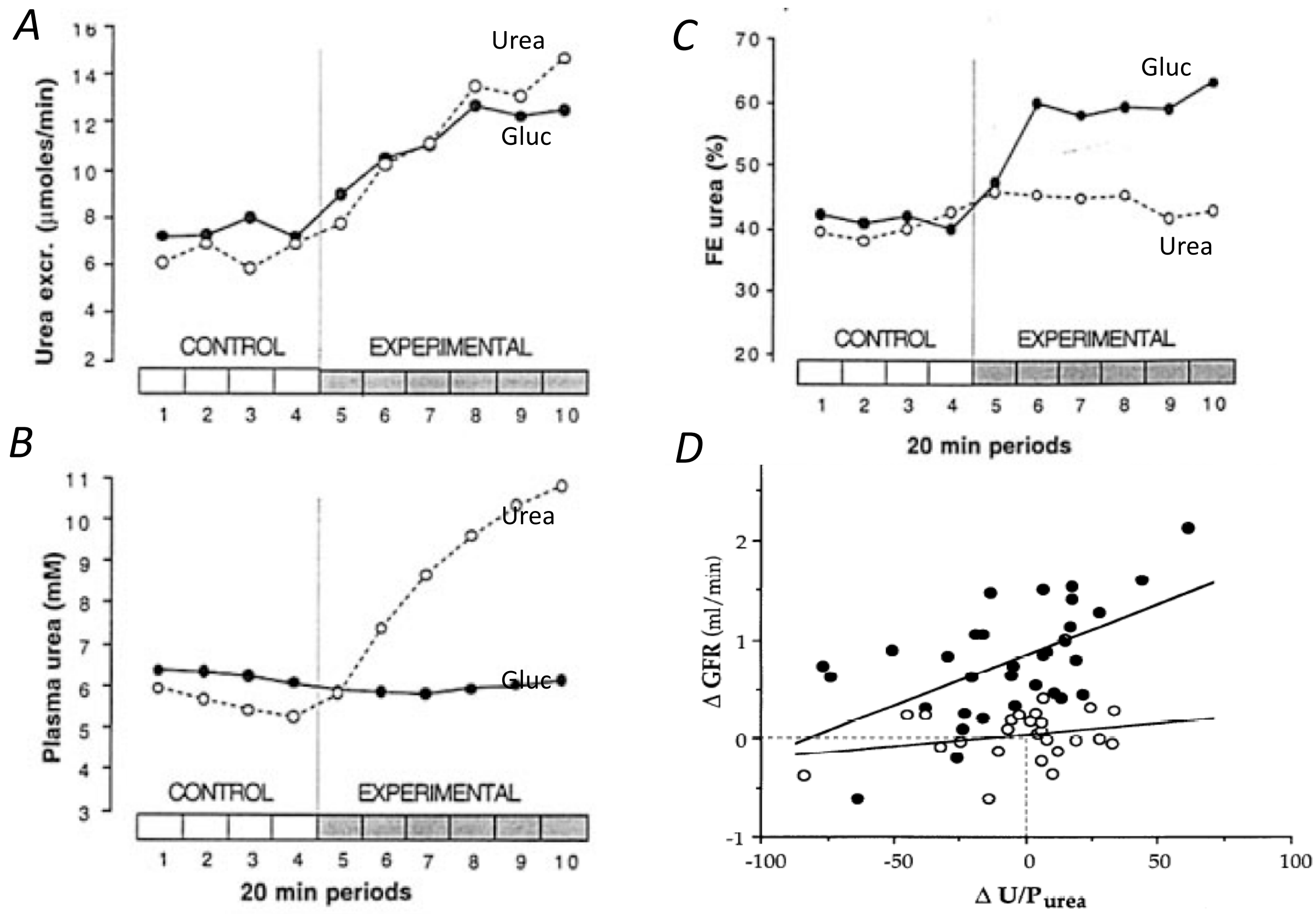

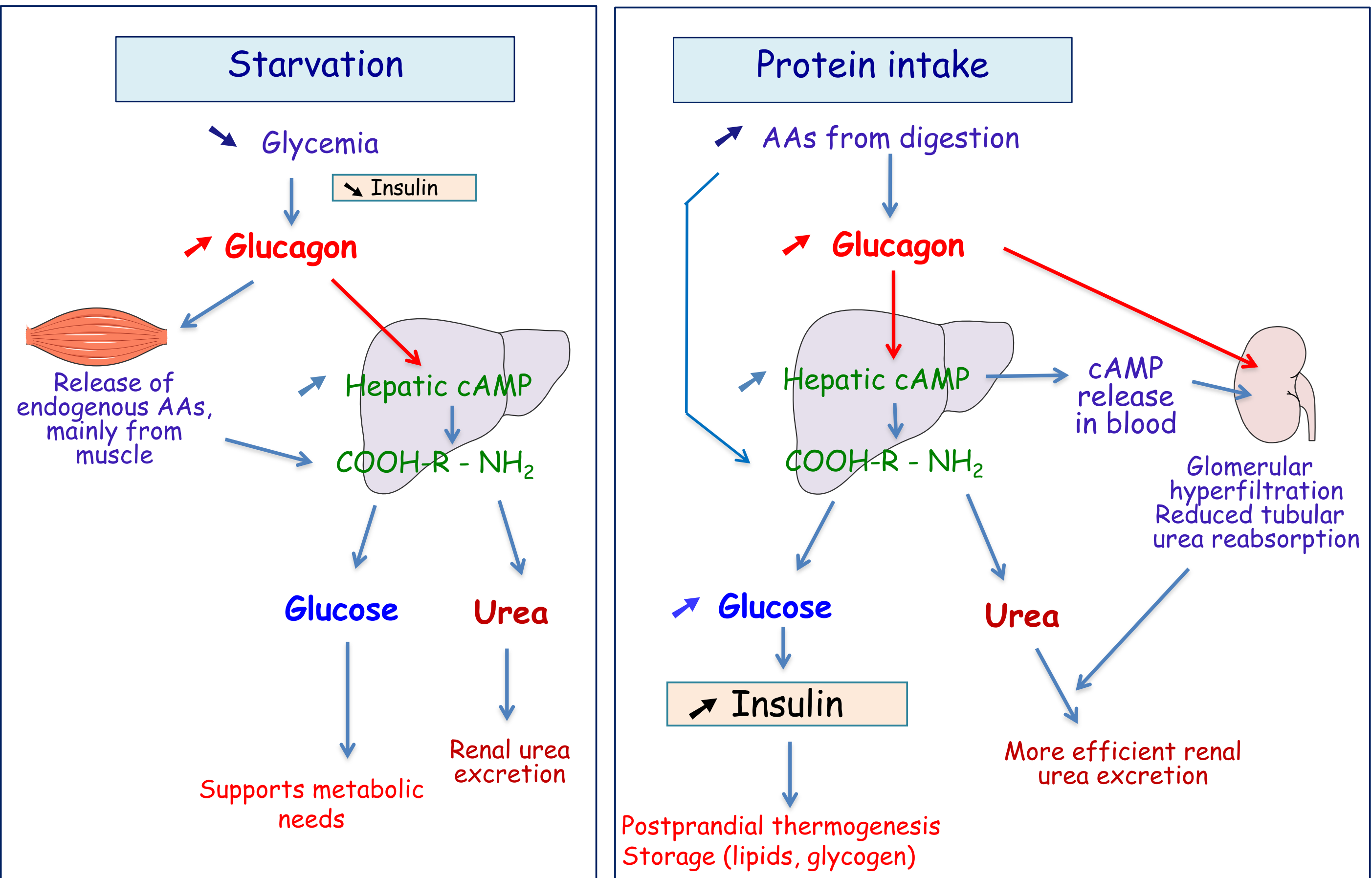